\title{
Mathevolepis alpina sp. n. (Cestoda: Hymenolepididae) from an alpine shrew: the first record of the genus in Europe
}

\author{
Rasa Binkienė and Leonas Kontrimavičius
}

Institute of Ecology, Nature Research Centre, Akademijos 2, Vilnius, 08412, Lithuania

\begin{abstract}
Mathevolepis alpina sp. n. is described from an alpine shrew, Sorex alpinus, from the Carpathian Region of the Slovak Republic. The new species differs from other species of the genus by the morphology of the male copulatory apparatus, especially the cirrus, which is characterised by asymmetrical parabasal swelling. The new species represents the first record of cestodes of the genus Mathevolepis Spassky, 1948 in Europe, i.e. the western part of the Palaearctic Region. The geographical distribution of species of Mathevolepis is reviewed.
\end{abstract}

Keywords: Cyclophyllidea, taxonomy, Sorex alpinus, Slovak Republic, High Tatras, Palaearctic Region, distribution

The genus Mathevolepis Spassky, 1948 was erected by Spassky (1948) for M. petrotschenkoi Spassky, 1948, a parasite of shrews (Soricidae) in Siberia. According to Spassky (1948), the genus was characterised by a very short strobila composed of only two proglottides, with the last proglottides released from the strobila before becoming fully gravid, unarmed scolex with a rudimentary rostellum and a sacciform uterus.

Significant contribution to the morphology of the type-species has been made by Gulyaev and Karpenko (1998), who redescribed M. petrotschenkoi and selected the neotype on the basis of a new material collected from the common shrew Sorex araneus L. in the north-eastern Altai mountains in Siberia. Live tapeworms were collected from freshly-dead shrews, allowing Gulyaev and Karpenko (1998) to precisely describe the morphological characteristics of the species and to reveal that hyperapolysis is not a generic character of Mathevolepis as Spassky (1948) assumed.

Gulyaev and Karpenko (1998) also observed that the full development of eggs in M. petrotschenkoi was completed inside the gravid uterus and that only proglottis with invasive eggs detached from the strobila. Moreover, Gulyaev and Karpenko (1998) noticed that M. petrotschenkoi could have up to four proglottides that were morphologically clearly distinct from each other, each corresponding to a part in a series of proglottides at the same stage of development as in other unarmed hymenolepidid tapeworms of the related genera Ditestolepis Spassky, 1954, Cucurbilepis Sadovskaya, 1965 and Ecrinolepis Spassky et Karpenko, 1983, which parasitize shrews (Spassky 1954, Sadovskaya 1965, Spassky and
Karpenko 1983, Gulyaev 1991). Gulyaev and Karpenko (1998) considered the reduction in the number of proglottides to four in the strobila of $M$. petrotschenkoi to represent oligomerization. For this reason, they amended the generic diagnosis of Mathevolepis to include also species with more than four proglottides. They also transferred Cucurbilepis skrjabini Sadovskaya, 1965 and Hymenolepis macyi Locker et Rausch, 1952 to Mathevolepis and excluded two other species, namely Mathevolepis triovaria Karpenko, 1990 and M. morosovi Karpenko, 1994, from the genus and later placed them in the new genus Brachyolepis Karpenko et Gulyaev, 1999 (Karpenko and Gulyaev 1999).

Since then, another two new species of Mathevolepis, M. junlanae Melnikova, Lykova et Gulyaev, 2004 from Russian Far East and M. ketenchievi Irzhavsky, Gulyaev et Lykova, 2005 from Central Caucasus, were described. Lykova et al. (2006) redescribed Mathevolepis larbi Karpenko, 1982 from Yakutia and assumed that it is not the synonym of Cucurbilepis sorextscherskii Morozov, 1957 as Gulyaev (1991) proposed. Consequently, Mathevolepis currently includes six species, all specific parasites of shrews. These are M. petrotschenkoi, M. skrjabini (Sadovskaya, 1965), M. macyi (Locker et Rausch, 1952), M. larbi, M. junlanae and M. ketenchievi.

Re-examination of cestodes of shrews collected by J. Mituch (Mituch 1968), currently deposited in the Eastern Slovak Museum in Košice, revealed that specimens designated as Insectivorolepis (= Soricinia) globosa (Baer, 1931) from Sorex alpinus Schinz did not morphologically correspond to the diagnosis of this species. Moreover, S. globosa was originally described by Baer (1931) from 
a shrew of the genus Neomys Kaup. The results of the examination of these specimens supported their allocation into the genus Mathevolepis as a new species. The aim of the present study is to describe this new species and to review the geographical distribution of all species of the genus.

\section{MATERIALS AND METHODS}

Unstained tapeworms from Mituch's collections were fixed in formaldehyde and stored in one vial labelled as Insectivorolepis globosa from the shrew Sorex alpinus collected in 1958 from the High Tatras in the Slovak Republic. Four specimens were removed from vial and washed in tap water. Three of them were stained with Ehrlich's haematoxylin or iron acetocarmine, differentiated in $70 \%$ ethanol with hydrochloric acid, then dehydrated in an ascending ethanol series, cleared in clove oil and mounted in Canada balsam. One specimen was mounted in Berlese's medium to facilitate examination of the copulatory apparatus.

Measurements are presented in micrometres $(\mu \mathrm{m})$ unless otherwise stated. The range of metrical data is given, with the mean and number of specimens measured in parentheses. Type specimens of the present species are deposited in the Natural History Museum, Geneva (MNHG), in the collection of the Laboratory of Parasitology of the Institute of Ecology of Nature Research Centre, Lithuania (EKOI) and in the Helminthological Collection, Institute of Parasitology, Biology Centre, Academy of Sciences of the Czech Republic, České Budějovice (IPCAS).

\section{RESULTS}

\section{Mathevolepis alpina sp. n.}

Fig. 1

Description (based on four specimens). Body very small, flattened. Total length of entire pregravid specimens $1.5-1.9 \mathrm{~mm}(1.6 \mathrm{~mm}, \mathrm{n}=3)$ and maximum width 205-248 (230, $\mathrm{n}=3)$, consist of 10-12 proglottides (Fig. 1A). Strobilization serial. Strobila with very rapid protandrous development. Three clear series of proglottides each containing 3-4 proglottides at same stage of development observed in each strobila. First series represented by proglottides with underdeveloped male gonads, second series by mature hermaphroditic proglottides and third series by pregravid proglottides with developing uterus.

Scolex oval, relatively large, 176-204 long and 201259 wide $(187 \times 235, \mathrm{n}=3)$ (Fig. 1B). Suckers oval, 147 $174 \times 90-122(161 \times 107, \mathrm{n}=12)$, with well-marked muscular walls. Glandular sac-like rostellum, unarmed, 60-67 long and 26-33 wide $(64 \times 29, \mathrm{n}=3)$. Rostellar sac absent. Neck very short, $134-163(147, \mathrm{n}=3)$ wide. Proglottides acraspedote. Juvenile proglottides much wider than long, 14-50 long and 112-168 wide $(25 \times 140, \mathrm{n}=12)$, mature proglottides slightly wider than long or almost as long as wide, $73-154 \times 137-211(106 \times 172, \mathrm{n}=11)$, pregravid proglottides longer than wide, $212-284 \times 165-248$ (243 $\times 205, \mathrm{n}=11)$.
Two pairs of osmoregulatory canals, divide proglottides into three almost equal parts; transverse anastomoses not observed. Ventral osmoregulatory canals with diameter 3-5 $(4, \mathrm{n}=6)$, dorsal osmoregulatory canals with diameter $1-2(2, n=6)$. Lateral fields of proglottides 44-67 $(54, \mathrm{n}=12)$ wide. Genital pore dextral, opens anteriorly to middle of lateral proglottis margin. Genital atrium cylindrical, 14-24 deep (20, $n=9)$, surrounded by intensely stained cells (Fig. 1C). Genital ducts pass dorsal to osmoregulatory canals.

Testes three, oval, $27-44 \times 28-44(37 \times 36, \mathrm{n}=15)$, disposed in a right-angled triangle in median field of proglottis, where two antiporal testes lie one above another, more or less overlapping female gonads (Fig. 1C). Cirrus-sac elongated, bow-shaped, thin-walled, 143-244 $\times 13-18(178 \times 16, \mathrm{n}=10)$, crosses antiporal osmoregulatory canals (Fig. 1C,E). Partly-evaginated cirrus almost conical, with small asymmetrical parabasal swelling marked only in lateral view of cirrus (Fig. 1D). Evaginated part of cirrus $36-87$ in length and 9-14 $(10, n=4)$ in width, invaginated part of cirrus 124-176 in length; total length of cirrus 160-263 $(194, n=4)$. Cirrus covered with needle-shaped spines of different size. Length of spines at base 2.5-3.9 (3.0, $\mathrm{n}=15)$, at middle part 4.4-6.3 (5.3, $\mathrm{n}=30$ ) (Fig. 1D,E), in distal part their size decreases to $0.8-1.0(0.9, \mathrm{n}=10)$. External seminal vesicle elongate, $35-53 \times 9-16(46 \times 12, \mathrm{n}=8)$, usually bent along dorsal side of cirrus-sac, reaching middle line (Fig. 1C). Internal vas deferens forms few coils inside antiporal part of cirrus-sac. Internal seminal vesicle indistinguishable.

Ovary trilobed, 50-63 × 20-33 $(56 \times 26, \mathrm{n}=10)$, in centre of median field, ventral to testes; lobes oval, 23-31 $\times 16-27(26 \times 21, n=9)$. Vitellarium compact, rounded, $23-29 \times 16-20(26 \times 18, \mathrm{n}=10)$, posterior to ovary (Fig. 1C). Seminal receptacle elongates alongside midline. Vagina tubular, thin-walled, 85-104 × 7-11 $(92 \times 9, \mathrm{n}=8)$, runs parallel with and ventral to cirrus-sac and opens ventrally to genital atrium. Vagina with sphincter, 8-10 $\times 4-5$ $(9 \times 5, \mathrm{n}=8)$ in middle part, sphincter lies at a distance of $26-47(36, n=8)$ from vaginal aperture (Fig. 1C,E). Uterus in pregravid proglottides sac-like, 154-200 × 65-94 $(168 \times 76, \mathrm{n}=10)$; occupying almost entire median field, not crossing osmoregulatory canals (Fig. 1A). Fully-developed uterus not observed. Immature eggs numerous (up to 64-83), 7-10 $(9, \mathrm{n}=20)$ in diameter.

Ty pe host: Sorex alpinus Schinz (Soricomorpha: Soricidae). Site: Intestine.

Type locality: High Tatras, Western Carpathian Region, Slovak Republic.

Type specimens: Holotype: complete worm MHNG INVE 78871, Slovak Republic, 1958. Paratypes: complete worms EKOI HELMI 444 and IPCAS C-624.

E ty mology: The species name refers to the name of the definitive host. 
A

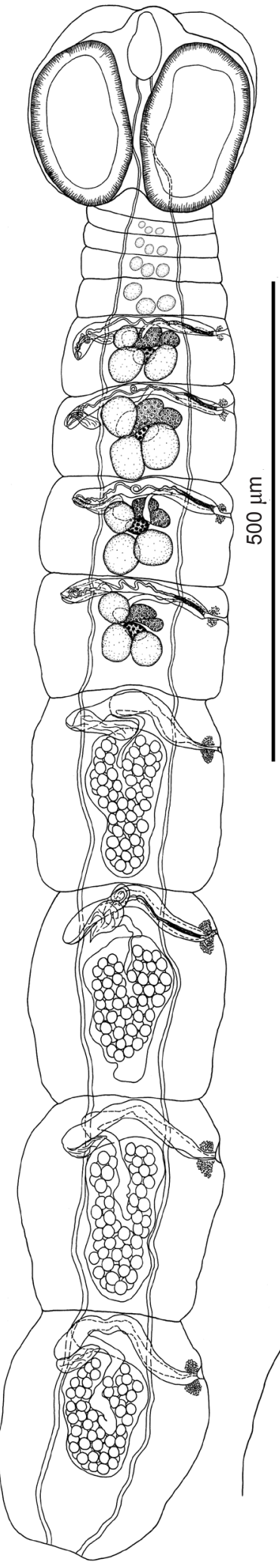

B

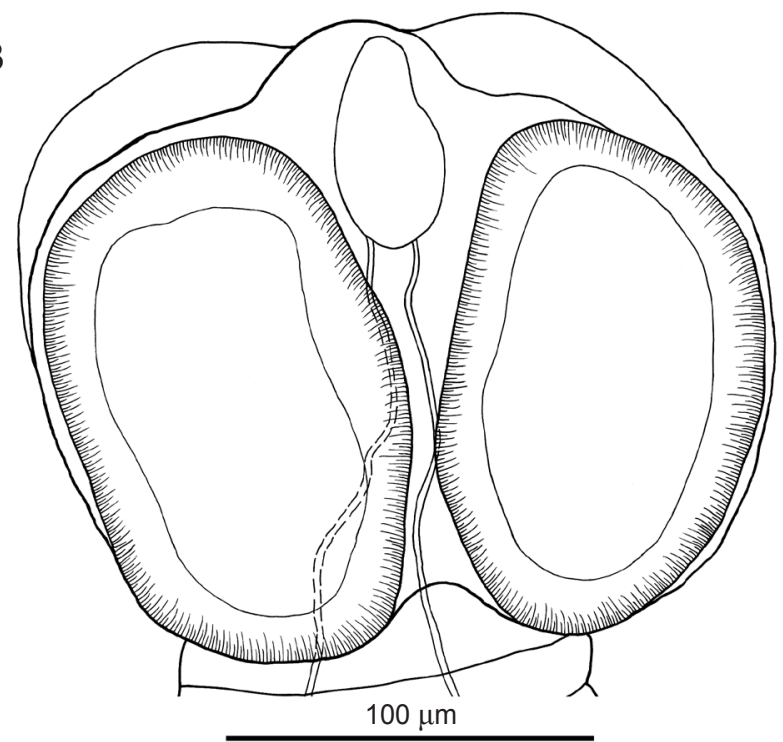

C

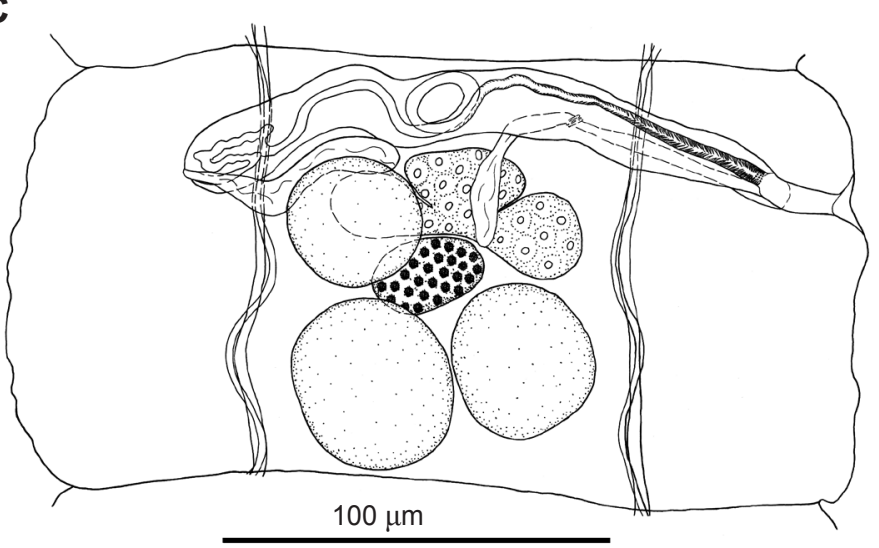

D

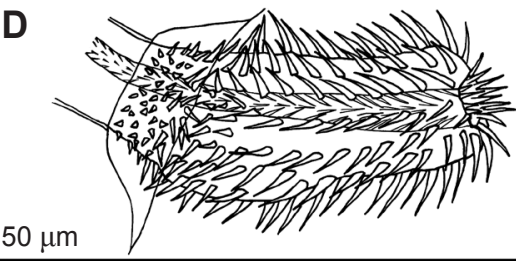

E

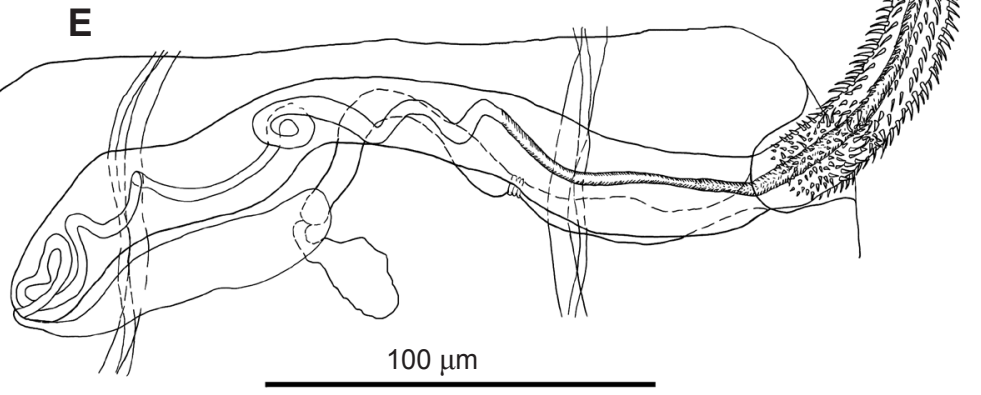

Fig. 1. Mathevolepis alpina sp. n. A - total view of mature specimen (holotype); B - scolex; C - mature hermaphroditic proglottis; $\mathbf{D}$ - cirrus; $\mathbf{E}$ - genital ducts. 
Table 1. Hosts and distribution of species of the genus Mathevolepis in the Holarctic Region.

\begin{tabular}{|c|c|c|}
\hline Species & Host (Sorex species) and source & Locality and source \\
\hline $\begin{array}{l}\text { Mathevolepis petrotschenkoi Spassky, } 1948 \\
\quad \text { (type species ) }\end{array}$ & $\begin{array}{l}\text { S. araneus }(4,9,13,14), S . \text { caecutiens } \\
(9,20,13), S . \text { daphaenodon }(20), \\
\text { S. isodon }(13,20), S . \text { minutus }(9,13), \\
\text { S. minutissimus }(20), \text { S. roboratus }(13), \\
\text { Sorex spp. }(2,17,30)\end{array}$ & $\begin{array}{l}\text { West Siberia }(4,9,13,14,30) \text {, Magadan } \\
\text { region }(20) \text {, Primorskiy Krai }(17) \text {, Chu- } \\
\text { kotka }(2,17) \text {, Kolyma Mts. (2) }\end{array}$ \\
\hline $\begin{array}{l}\text { Mathevolepis macyi (Locker et Rausch, 1952) Gulyaev et } \\
\text { Karpenko, } 1998 \\
\quad \text { Syn.: Hymenolepis macyi Locker et Rausch, 1952; } \\
\text { Soricina macyi (Locker et Rausch, 1952) Zarnowski, } 1956\end{array}$ & $\begin{array}{l}S . \text { bendirii }(12,19), S . \text { cinereus }(11,12 \text {, } \\
31), S . \text { ornatus }(1,12), S . \text { trowbridgei } \\
(12,32), S . \text { vagran }(10,12,15,29)\end{array}$ & $\begin{array}{l}\text { North America }(12) \text {, California }(1,31) \text {, } \\
\text { Iowa }(32) \text {, Montana }(10,29) \text {, Oregon } \\
(15,19) \text {, Pennsylvania }(11,15)\end{array}$ \\
\hline $\begin{array}{l}\text { Mathevolepis skrjabini (Sadovskaya, 1965) Gulyaev et } \\
\text { Karpenko, } 1998 \\
\text { Syn.: Cucurbilepis skrjabini Sadovskaya, 1965; Cucurbi- } \\
\text { lepis trifolia Karpenko, 1983; Soricinia japonica Sawada } \\
\text { et Koyasu, 1991; Sinuterilepis diglobovary sensu Eltyshev, } \\
1975 \text { nec Sadovskaya, } 1965\end{array}$ & $\begin{array}{l}\text { S. araneus }(4,5,9,13,14), S . \text { caecutiens } \\
(3,8,13,14,23), S . \text { isodon }(13,14,28), \\
\text { S. minutus, S. roboratus }(13), \text { S. shinto } \\
(25,26), \text { S. unguiculatus }(23,24,27) \\
\text { Sorex sp. (22) }\end{array}$ & $\begin{array}{l}\text { Khabarovskiy krai (8), West Siberia } \\
(4,9,13,14,28) \text {, Primorskiy krai }(17, \\
\text { 22), Barguzin Valley (3), Yakutiya }(21), \\
\text { Tyumenskaya oblast' (5), Japan }(23,24, \\
\text { 25, 26), South Sakhalin (27) }\end{array}$ \\
\hline $\begin{array}{l}\text { Mathevolepis larbi Karpenko, } 1982 \\
\text { Syn.: M. larbicus Karpenko, } 1982 \text { according Lykova et al. } \\
\text { (2006) }\end{array}$ & $\begin{array}{l}\text { S. caecutiens }(21), \text { S. roboratus }(7) \text {, } \\
\text { S. unguiculatus }(16)\end{array}$ & $\begin{array}{l}\text { Amurskaya oblast' (7), Buryatskaya } \\
\text { ASSR (7), Sakhalin (16), Yakutiya (21) }\end{array}$ \\
\hline Mathevolepis junlanae Melnikova, Lykova et Gulyaev, 2004 & S. caecutiens $(18)$ & Primorskiy Krai (18) \\
\hline Mathevolepis ketenchievi Irzhavskii, Gulyaev et Lykova, 2005 & S. caucasica (6), S. raddei (6) & Central Caucasus (6) \\
\hline Mathevolepis alpina sp. n. & S. alpinus* & Slovak Republic* \\
\hline
\end{tabular}

* - present study. Authors: 1 - Davis and Voge (1957)\#; 2 - Dokuchaev et al. (2003); 3 - Eltyshev (1975) $; 4$ - Gulyaev and Karpenko (1998) 5 - Hritanko and Gashev (2005); 6 - Irzhavskiy et al. (2005)\#; 7 - Karpenko (1982);; 8 - Karpenko (1983); 9 - Karpenko (1998); 10 - Kinsella (2007); 11 - Kinsella et al. (2008); 12 - Kinsella and Tkach (2009); 13 - Kornienko (2001); 14 - Kornienko and Gulyaev (2002); 15 - Locker and Rausch (1952); 16 - Lykova et al. (2006); 17 - Melnikova et al. (2003); 18 - Melnikova et al. (2004); 19 - Neiland (1953); 20 - Novikov $(1995)^{\#} ; 21$ - Odnokurcev and Karpenko (1993); 22 - Sadovskaya (1965); 23 - Sawada (1999); 24 - Sawada and Koyasu (1991) ${ }^{\#} ; 25$ - Sawada et al. (1992); 26 - Sawada and Harada (1993)*; 27 - Sawada and Kobayashi (1993); 28 - Sawada et al. (1995); 29 - Senger (1955); 30 - Spassky (1948) 31 - Voge $(1955)^{\# ;} 32$ - Wittrock and Hendrickson (1979). Articles containing descriptions marked by \#.

\section{DISCUSSION}

The pattern of strobilation and strobilar morphology of Mathevolepis alpina correspond well to the generic diagnosis of Mathevolepis as amended by Gulyaev and Karpenko (1998). All known species of the genus are specific to shrews of the genus Sorex (Locker and Rausch 1952, Spassky 1954, Sadovskaya 1965, Karpenko 1982, Spassky and Karpenko, 1983, Gulyaev 1991, Gulyaev and Karpenko 1998, Melnikova et al. 2004, Gulyaev and Lykova 2005, Lykova et al. 2006).

Two species of Mathevolepis possess a markedly different number of proglottides in the strobila from that of M. alpina. These are the type-species $M$. petrotschenkoi (the number of proglottides 2-4) and M. skrjabini (up to 45 proglottides). The remaining four species have a number of proglottides closer to that of M. alpina. Mathevolepis ketenchievi has 12-15 proglottides, M. larbi 12-18 proglottides, M. macyi 12-18 proglottides and M. junlanae 9-12 proglottides. One of the most reliable differentiating characters of the new species is the structure of the male copulatory apparatus. The cirrus of M. alpina (160-263 $\mu \mathrm{m}$ in length) is unique in having a small asymmetrical swelling on the parabasal part of the cirrus, which is well noticeable on the partly-evaginated cirrus (Fig. 1D).

Mathevolepis ketenchievi, described from two species of Sorex in the Central Caucasus, corresponds closely to $M$. alpina, but differs in the possession of a longer cirrussac (320-360 $\mu \mathrm{m}$ long) curved in the form of the letter "M" and a cirrus (350-400 $\mu \mathrm{m}$ long) with a symmetri- cal basal swelling. The number of eggs in the uterus of M. ketenchievi is greater (140-160) than that of M. alpina.

Mathevolepis larbi, described from shrews in Eastern Siberia, has a cirrus-sac 170-210 $\mu \mathrm{m}$ long and the sac does not cross the antiporal osmoregulator canals, and a cirrus is $170-200 \mu \mathrm{m}$ long, without swellings. Moreover, the vaginal sphincter of $M$. larbi is situated in the entry of the copulatory part of the vagina in the genital atrium and the number of eggs in its uterus is about 150 (Lykova et al. 2006).

Mathevolepis junlanae described from $S$. caecutiens in Primorskyi Krai is characterised by a short straight cirrussac (100-150 $\mu \mathrm{m}$ long), which crosses the middle line but does not reach antiporal osmoregulator canals, a cirrus (up to $92 \mu \mathrm{m}$ long and $14-15 \mu \mathrm{m}$ wide) is with symmetrical parabasal swelling, a vaginal sphincter is situated near the female orifice and the number of eggs in the uterus is about 140-160.

Mathevolepis macyi, a common parasite of shrews in North America, has a cirrus-sac up to $140 \mu \mathrm{m}$ long, cirrus is without swelling, being armed with numerous hairshaped, very slender spines, and eggs are 30-40 $\mu \mathrm{m}$ in diameter (Davis and Voge 1957).

According to all available data (see Table 1), the species of the genus Mathevolepis are unevenly distributed throughout the Holarctic Region. Most species have been found in the eastern part of the Palearctic Region: four species in Siberia and one species in Caucasus, whereas one species was found in the Nearctic Region (North America). Some records of Mathevolepis spp. (Neiland 
1953, Senger 1955, Wittrock and Hendrickson 1979, Sawada et al. 1992, Odnokurcev and Karpenko 1993, Sawada and Kobayashi 1993, Sawada et al. 1995, Karpenko 1998, Sawada 1999, Kornienko 2001, Kornienko and Gulyaev 2002, Dokuchaev et al. 2003, Melnikova et al. 2003, Hritanko and Gashev 2005, Kinsella 2007, Kinsella et al. 2008, Kinsella and Tkach 2009) were not accompanied by data on the morphology of the specimens and need further confirmation (Table 1). Mathevolepis alpina is the only species of the genus Mathevolepis found in the European part of the Palaearctic Region.

Acknowledgements. We are grateful to M. Špakulová and V. Hanzelová for their aid in the re-examination of J. Mituch's collection, to S.K. Kornienko and A. Makarikov for their advice during the preparation of figures, to T. Scholz and reviewers for reading the manuscript and making useful suggestions, and, especially, to S. Bondarenko and V. Kontrimavičius for their substantial help and criticism in preparing this article.

\section{REFERENCES}

BAER J.G. 1931: Helminthes nouveaux parasites de la musaraigne d'eau, Neomys fodiens Pall. (Note preliminaire). Actes Soc. Helv. Sci. Nat. 112: 338-340.

DAvis B.S., Voge M. 1957: Observations on Hymenolepis macyi Locker and Rausch, with a revised diagnosis of this cestode. Proc. Helminthol. Soc. Wash. 24: 1-4.

Dokuchaev N.E., Melnikova J.A., Gulyaev V.D. 2003: [Cestodes of shrews in Kamchatka and adjacent areas.] In: A.M Tokranov (Ed.), Conservation of Biodiversity of Kamchatka and Coastal Waters (Materials of IV Scientific Conference, Petropavlovsk), pp. 39-42. (In Russian.)

Eltyshev Y.A. 1975: [Fauna of helminths of mammals from Barguzin depression and experience of its geographical analysis I. The systematic review.] In: V.L. Kontrimavichus (Ed.), Paraziticheskiye Organizmy Severo-Vostoka Azii. Vladivostok, Academy of Sciences of USSR, Far-East Science Centre, pp. 135-167. (In Russian.)

Gulyaev V.D. 1991: [Morphology and taxonomy of Ditestolepidini - Cestodes (Cyclophyllidea) of shrews with the seriesmetameric structure of the strobiles.] Zool. Zh. 70: 44-53. (In Russian.)

Gulyaev V.D., Karpenko S.A. 1998: [Cestode of the genus Mathevolepis Spassky, 1948 (Cyclophyllidea: Hymenolepididae) from shrews of Holarctic.] Parazitologiya 32: 507-518. (In Russian.)

Gulyaev V.D., Lykova K.A. 2005: [The morphological features of the triba Ditestolepidini Spassky 1954]. In: Abstract of Interregional Conference of Siberia and Far East of Russia, Novosibirsk, pp. 45-47. (In Russian.)

Hritanko O.A., Gashev S.N. 2005: [Communities of helminths of Soricidae in the south part of a forest zone of the Tyumenskaya oblast'.] In: Abstracts of the Interregional Conference of Siberia and Far East of Russia, Novosibirsk, pp. 226-227. (In Russian.)

Irzhavskiy S.V, Gulyaev V.D., Lykova K.A. 2005: [Ecrinolepis safarbii and Mathevolepis ketenchievi - new species of cestodes of tribe Ditestolepidini (Cyclophyllidea, Hymenolepididae) of shrews from Central Caucasus.] Zool. Zh. 84: 10411049. (In Russian.)

KARPENKo S.A. 1982: [Mathevolepis larbi is a new species of the genus Mathevolepis Spassky, 1948 (Cestoda, Hymenolepididae) in shrews from Eastern Siberia.] In: A.I. Cherepanov, N.A. Violovich, G.S. Zolotorenko and I.A. Tibatina (Eds.), Gelminty, Kleshchi i Nasekomye. Nauka, Novosibirsk, pp. 4-13. (In Russian.)

Karpenko S.A. 1983: [Two new hymenolepid cestode species of shrews from Baikal - Amur pathway.] In: Izvestiya Sibirskogo Otdeleniya Akademii Nauk SSSR, Seriya Biologicheskih Nauk, 2: 125-132. (In Russian.)
Kar PEnKo S.A. 1998: [Helminths of shrews from submountain region of Western Altai.] In: Parasites in Natural Complexes and Disturbed Situations. Abstracts of conference, Novosibirsk, pp. 69-71. (In Russian.)

Karpenko S.A., Gulyaev V.D. 1999: [Brachylepis gen. n. - a new cestode genus (Cyclophyllidea: Hymenolepididae) from shrews of Siberia and Russian Far-East.] Parazitologiya 33: 410-419. (In Russian.)

Kinsella J.M. 2007: Helminths of the vagrant shrew, Sorex vagrans, from western Montana, USA. Acta Parasitol. 52: 151155.

Kinsella J.M., TKach V.V. 2009: Checklist of helminth parasites of Soricomorpha (= Insectivora) of North America north of Mexico. Zootaxa 1969: 36-58.

Kinsella J.M., Vandegrift K.J., Grant L.K., Bozick B.A., Hudson P.J. 2008: Gastrointestinal helminths of the masked shrew, Sorex cinereus, from Pennsylvania. Comp. Parasitol. 75: 141-144.

Kornienko S. 2001: [Cestodes of shrews from North-Eastern Altai (taxonomy, systematic and ecology).] PhD thesis, Institute of Animal Systematics and Ecology, Siberian Division, Russian Academy of Science, Novosibirsk, 23 pp. (In Russian.)

Kornienko S.A., Gulyaev V.D. 2002: [Cestode distribution in shrew population in taiga of Teletskoye lake.] In: Parazitologicheskie Issledovaniya v Sibiri i na Dal'nem Vostoke. Materialy mezhdunarodnoi nauchnoi konferentsii, Novosibirsk, 2002, pp. 61-63. (In Russian.)

Locker B., Rausch R. 1952: Some cestodes from Oregon shrews, with descriptions of four new species of Hymenolepis Weinland, 1858. J. Wash. Acad. Sci. 42: 26-31.

Lykova K.A., Gulyaev V.D., Melnikova Yu.A., Karpenko S.V. 2006: [On the species independence of Mathevolepis larbi Karpenko, 1982 (Cyclophyllidea: Hymenolepididae: Ditestolepidini).] Parazitologiya 40: 299-305. (In Russian.)

Melnikova Yu.A., Gulyaev V.D., Dokuchaev N.E. 2003: [The structure of shrew cestode community in western Beringia and Far East.] In: A.N. Alekseev, T.V. Beier, K.V. Galaktionov, E.V. Dubinina and O.N. Pugachev (Eds.), Problems of Modern Parasitology II. International conference and congress of the Parasitological Society of Russian Academy of Science, Petrozavodsk, 2003, pp. 18-20. (In Russian.)

Melnikova Yu.A., Lykova K.A., Gulyaev V.D. 2004: [Mathevolepis junlanae sp. n. (Cyclophyllidea: Hymenolepididae: Ditestolepidini), a new cestode species from shrews of Far East.] Parazitologiya 38: 541-546. (In Russian.)

Mituch J. 1968: Index helminthum. In: Studia Helminthologica II. Slovenská akadémia vied. Helmintologický ústav, Bratislava, pp. 221-279.

NeILAND K.A. 1953: Helminths of northwestern mammals, part V. Observations on cestodes of shrews with the descriptions of 
new species of Liga Weinland, 1857, and Hymenolepis Weinland, 1858. J. Parasitol. 39: 487-495.

Novikov M.V. 1995: Cestodes of shrews (Insectivora, Soricidae) from the Magadan region, North-East Siberia. Acta Parasitol. Pol. 40: 37-42.

OdnokurceV V.A., Karpenko S.V. 1993: [The structure of helminth fauna of shrews from Yakutiya.] In: A.A. Spassky and P.I. Nesterov (Eds.), Fauna, Ecologiya i Prakticheskoe Znachenye Fito- i Zooparaziticheskikh Organizmov. Stinitsa, Kishinev, pp. 65-76. (In Russian.)

Sadovskaya N.P. 1965: [On fauna of cestodes of insectivorous from Primorskiy kray.] In: V.A. Leonov, Y.L. Mamaev and P.G. Oshmarin (Eds.), Paraziticheskye Chervi Domashnikh i Dikikh Zhivotnych. Vladivostok, pp. 290-297. (In Russian.)

SAWADA I. 1999: A checklist of cestode species from Asian Insectivora. Nara Sangyo Univ. J. Ind. Econ. 13: 109-123.

Sawada I., Harada M. 1993: Cestode parasites of shinto shrew, Sorex shinto shinto from Chino City, Nagano Prefecture, Japan. Bull. Nara Sangyo Univ. 9: 147-155.

Sawada I., Harada M., Koyasu K. 1992: Helminth fauna of shrews at the base of Mt. Hakusan in Ishikawa Prefecture, Japan. Bull. Nara Sangyo Univ. 8: 153-164.

Sawada I., Harada M., Oda S. 1995: Further studies on cestode parasites of some micromammalians (Insectivora) from
Akademgorodok city and Altai Region, Russia. Proc. Jpn. Soc. Syst. Zool. 54: 19-27.

Sawada I., Kobayashi S. 1993: Cestode parasites of shrews in South Saghalien. Proc. Jpn. Soc. Syst. Zool. 49: 1-5.

Sawada I., Koyasu K. 1991: Cestodes of some micromammalians (Insectivora) from Hokkaido, Japan. Jpn. J. Parasitol. 40: $567-575$.

Senger C.M. 1955: Observations on cestodes of the genus Hymenolepis in North American shrews. J. Parasitol. 41: 167-170

SPASSKY A.A. 1948: [Mathevolepis petrotschenkoi nov. gen. nov. sp., a new species with uterine pore.] Dokl. AN SSSR 8: 15131515. (In Russian.)

SPASSKY A.A. 1954: [Classification of hymenolepidids of mammals]. Trudy Gel'mintologicheskoi Laboratorii Akademii Nauk SSSR. 7: 120-167. (In Russian.)

Spassky A.A., KarpenKo S.A. 1983: [A new genus of hymenolepidid cestodes from insectivorous.] Izvestiye AN Moldavskoi SSR. Seria biologicheskih i chimicheskih nauk. Parazitologiya 3: 56-61. (In Russian.)

Voge M. 1955: A list of cestode parasites from California mammals. Am. Midl. Nat. 54: 413-417.

Wittrock D.D., Hendrickson G.L. 1979: Helminths of shrews, Blarina brevicauda and Sorex cinereus, in Iowa. J. Parasitol. 65: 985-986. 